\title{
POLISH WOMEN MICRO-ENTREPRENEURS FROM THE MAZOVIA PROVINCE: PURSUED GOALS, ADOPTED BUSINESS STRATEGY, AND FIRM CHARACTERISTICS
}

\author{
Dariusz Leszczyński*
}

\begin{abstract}
Background. Women-owned businesses are important contributors to the job and wealth creation in many countries around the world. However, they are significantly understudied within transition economies from Central and Eastern Europe.
\end{abstract}

Research aims. The primary objective was to determine the socio-demographic profile of women micro-entrepreneurs from Poland's Mazovia Province. The secondary objective was to describe the possessed resources and the characteristic features of their businesses.

Methodology. A survey was carried out using an Internet-based self-administered questionnaire. The data collection process was outsourced to a professional research company to ensure its validity and reliability. Univariate statistical techniques were employed to explore and analyse the 309 valid questionnaires.

Key findings. Women micro-entrepreneurs prefer to operate as sole proprietors and are predominately active in the services sector. They mainly use their own financial resources to fund business operations. Female business owners tend to pursue personal type goals (e.g. "realisation of personal objectives or life passions"). They adopt an informal business strategy to achieve a competitive advantage over their competitors. It involves product/service differentiation, improvement of service quality, or a specific customer segment focus. However, the business strategies used by women rarely concentrate on long-term firm growth.

Keywords: business goal, business strategy, micro-enterprise, Poland, woman micro-entrepreneur.

Warsaw School of Economics, E-mail: dariusz.leszczynski@gmail.com 


\section{INTRODUCTION AND BACKGROUND}

Since the early 1980s, the number of women-owned businesses continues to rise in many countries around the world. They are currently recognised as important contributors to the job and wealth creation within the global economy (Kelley et al., 2013). Thus, many female business owners decided to enter into entrepreneurship as a more attractive alternative to full-time employment. Over time the growing importance of women-owned micro and small firms has attracted the attention of the academic community, which increased the volume of scientific investigations concerning this international research phenomenon (Carter et al., 2012).

Despite the growing contribution of female business owners to the progress of local communities in many countries around the world, the experiences of women entrepreneurs thus far have attracted only a minority interest of international scholars in comparison with their male counterparts (Brush et al., 2006). Moreover, although many studies were already carried out regarding this phenomenon in developed countries (e.g. the USA), there is still a scarcity of such investigations undertaken within the transition economies from Central and Eastern Europe (Balcerzak-Paradowska et al., 2011). Consequently, this paper is an attempt to bridge the existing research gap in this area.

The extant scientific literature concerning women's business ownership can be grouped into four broad categories by applying Gartner's (1985) conceptual framework. It was developed for the classification of studies regarding a new venture creation. Through the application of this theoretical approach we can identify four research dimensions for studying women entrepreneurship, namely: the individual or individuals, the organisation, the process, and the environment. In this paper, the first two categories of Gartner's (1985) typology were adopted to achieve the presented below research aims.

Within the individual or individuals' dimension, the studies focused on the attributes of women entrepreneurs and their socio-demographic characteristics, as well as their psychological traits (Valencia, 2007). According to the latest Global Entrepreneurship Monitor's study on women entrepreneurship, the most dominating age group of female business owners across the globe is classified within the 25 to 34 years 
age bracket. These women also have at least post-secondary (i.e. completed high school) or higher level of education (i.e. a completed university degree). Moreover, in many factor- and efficiency-driven economies (e.g. China) and most efficiency-driven economies (e.g. the USA) there are proportionately more educated women business owners than men (Kelley et al., 2015). The studies on the psychological traits of female entrepreneurs identified and classified their motivations to enter business ownership into "necessity-push" or "opportunity-pull" group of factors. Women influenced by the first category of variables are those who experienced dissatisfaction with their previous job, had difficulty in finding full-time employment or earned a low family income. In turn, females driven by the second category of factors decided to enter into entrepreneurship to take advantage of the emerging business opportunities or pursue personal goals. These motivational variables are associated with self-accomplishment, lifestyle aspirations, and a desire for social recognition (Orhan, 2005).

The investigations carried out within the organisation dimension examined the firms established by women in terms of the objects of ownership, the sectors of engagement, the type of management strategies deployed, the business performance of enterprises and the factors that contribute to the achievement of success (Valencia, 2007). The majority of female business owners begin to trade with less start-up capital in comparison with male entrepreneurs. They often use currently available mainstream technology and target established customer market segments. Consequently, women adopt a more conservative approach in terms of business formation because they are often driven to enter entrepreneurship by the "necessity-push" motivational factors (Allen et al., 2007). Female business owners are traditionally engaged predominately in the service sector and consumer-oriented economic activities. However, they are increasingly making inroads into a variety of other industries such as manufacturing or construction (Taylor \& Newcomer, 2005). Studies also suggest that many female-owned small firms underperform in comparison with male-owned businesses because they are constrained by specific socio-economic influences (e.g. homeworking, combining work commitments with childcare responsibilities, etc.). Moreover, women-run firms also experience more difficulty in access to external capital for growth (Carter et al., 2012). 
The research conducted within the process dimension on women entrepreneurship is associated with the examination of female startup activities, the strategies they adopted to compete with rivals in the marketplace and the different ways they organise their firms (Valencia, 2007). Women prefer to enter into entrepreneurship with a person they know very well (e.g. spouses, family members) or with whom they have maintained social relations for a long period of time (e.g. friends, work colleagues). They also feel more comfortable in co-managing the business with other female entrepreneurs by establishing an effective managerial team. Networking and social capital are also important for women in starting and managing their own firms (Aldrich et al., 2002).

Finally, studies on female entrepreneurship within the business environment dimension were concentrated on the accessibility and availability of external funding (e.g. debt financing); the role of informal social institutions (e.g. mentoring, networking), as well as the societal attitudes towards women business ownership from the cultural and family perspectives (Valencia, 2007). Research findings indicate that in developed countries banking institutions are not fulfilling adequately their market role as lenders with regards to women-owned businesses. Therefore, the access to external financing (e.g. bank loans, venture capital) is still a serious problem for many females who operate small firms because of their aversion to take on more risk. Moreover, banks prefer to provide loans to mature or growing larger firms, which are usually owned and managed by men (Coleman, 2000). However, such gender discrimination problems on the basis of firm size are more often encountered by women entrepreneurs in the factor- and efficiency-driven economies (Carter et al., 2012). Concerning social capital institutions, some studies found out that in contrast to male entrepreneurs, women establish business networks that consist of many informal linkages and involve only female members (Buttner \& Moore, 1997).

\section{Study objectives and research questions}

This study was undertaken to accomplish two main objectives. Firstly, to determine the socio-demographic profile of women micro-entrepreneurs from Poland's Mazovia Province. Secondly, to identify and describe the possessed resources and the characteristic features of their firms. 
Specifically, through the conduct of this scientific inquiry the author sought to find the answers to the following specific research questions:

1. What is the socio-demographic profile of women-owned or co-owned micro-enterprises within the region?

2. What is the most important goal pursued by women concerning their involvement in business ownership?

3. What kind of business strategies women micro-entrepreneurs adopted during 2011-2013 to gain an advantage over their competition in the industry within the local marketplace?

4. What kind of resources did women-owned or co-owned micro-enterprises possess during 2011-2013?

5. What are the main characteristic features of the micro-enterprises owned and managed by women in the region?

Mazovia Province, as a representative administrative region of Poland, was chosen to carry out this investigation due to:

1. The region's significant contribution to the country's economic growth in terms of the GDP per capita;

2. The largest market size in Poland in terms of the number of customers;

3. The currently achieved export and import levels;

4. The prospective potential growth of exports;

5. The region's unrivalled ability to attract the largest number of foreign investments in comparison with other administrative regions of Poland (Guzowska, 2011).

\section{METHOD}

The firms eligible for this study had to be active on the market for at least three years. Women-owned micro-enterprises from all sectors of the economy, as listed under the Polish classification of economic activity (i.e. "PKD 2007"), were included in the sampling frame. The number of employees hired by the business (i.e. the headcount) was used as the main identifier of the size of the firm. The total sample size for this scientific inquiry was determined at 3,000 women micro-entrepreneurs who directly owned (e.g. sole proprietorship) or co-owned (e.g. civil law partnership) their firms. The women-owned micro-enterprises were drawn using a systematic sampling method. 
To investigate the posed research questions, a cross-sectional study design was adopted using an Internet-based questionnaire. The design of the questionnaire, its online pilot testing, as well as the conduct of the actual survey was outsourced to a market research company. This firm is a member of the Polish Association of Public Opinion and Marketing Research Firms (i.e. OFBOR). The undertaken survey was carried out using a combination of CAWI (i.e. computer-assisted web interview) and CATI (i.e. computer-assisted telephone interview) data collection methods during September 10-30, 2014.

At the end of the study, 309 women micro-entrepreneurs from the region completed a valid online questionnaire, displaying an acceptable response rate of $14 \%$. The attained actual response rate was calculated by adopting a formula recommended by Bryman and Bell (2011, p. 189). Zikmund et al. (2009, p. 233) consider achieved response rates from E-mail or Internet-based surveys, which are between 10 and 15\%, as good measures of the data collection process when no special incentives are used (e.g. product samples, money vouchers, etc.).

The data set obtained from the research company was checked for omissions and consistency before being coded for statistical analysis. The actual data analysis process was carried out with the aid of the IBM $₫$ SPSS $₫$ Statistics 21 software package while all presented charts were made using the Microsoft Excel ${ }^{\circledR} 2013$ edition spreadsheet. It was undertaken in a descriptive fashion using univariate statistical methods.

\section{RESULTS}

\section{Socio-demographic profile of women micro-entrepreneurs}

Figure 1 reveals that the dominating age category of the surveyed women micro-entrepreneurs from the Mazovia Province was the "30-39 years" group (34.6\%), followed by the "40-49 years" group $(25.6 \%)$ and the " $50-59$ years" group (23\%). The least represented age category in the study was the "up to 29 years" group (3.2\%). These results suggest that most women within the region preferred to set up their own firms after the completion of formal education mainly at the tertiary level (see Figure 2). Thus, the majority of the studied women micro-entrepreneurs were in their $30 \mathrm{~s}$ or $40 \mathrm{~s}(60.2 \%)$. 


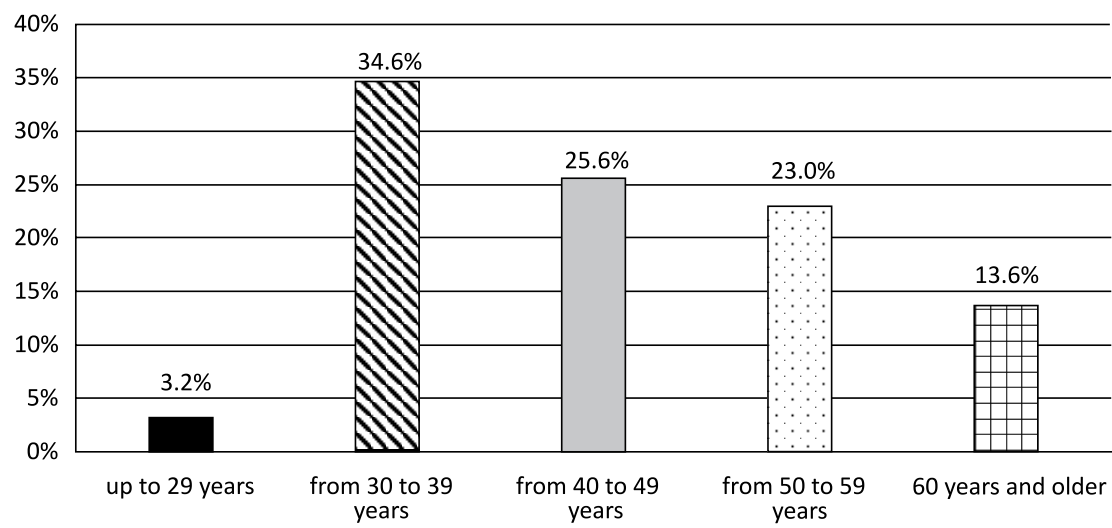

Figure 1. The age of women micro-entrepreneurs (\% share of total)

Source: own elaboration based on survey results. N=309 observations.

In turn, Figure 2 shows that $45 \%$ of the respondents declared the completion of some form of tertiary education while $33 \%$ of women reported that they also received a postgraduate diploma. Surprisingly, only $0.3 \%$ of female micro-entrepreneurs reported graduating from a vocational school while $9.7 \%$ of women micro-entrepreneurs declared that they completed high school. Thus, the overwhelming majority of female business owners who participated in the study (78\%) declared the completion of at least a university degree before entering into entrepreneurship.

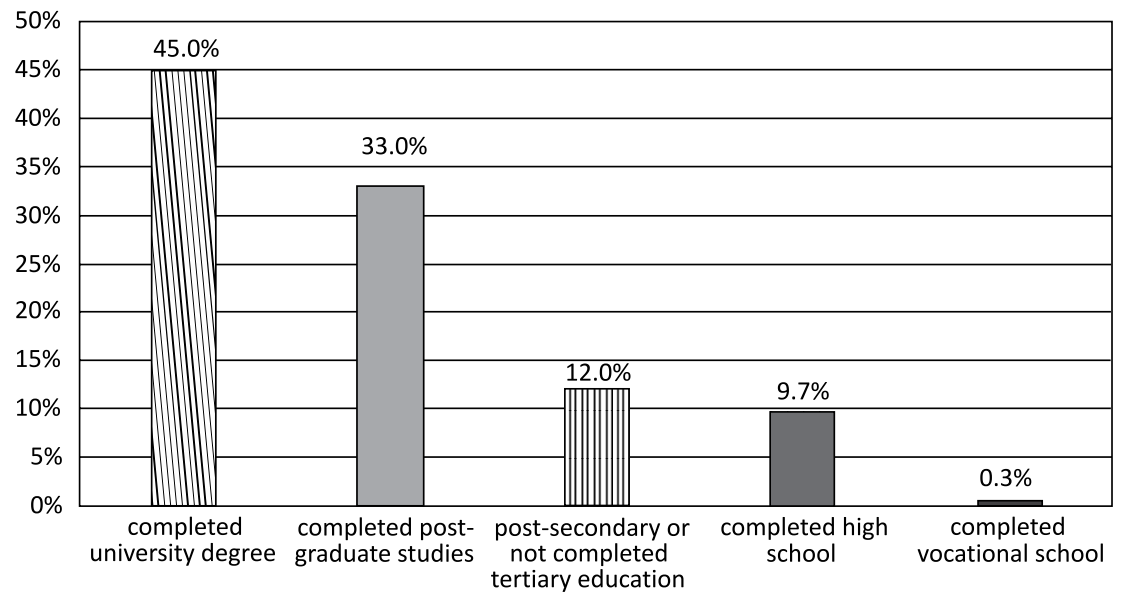

Figure 2. Completed formal education level by women micro-entrepreneurs (\% share of total)

Source: own elaboration based on survey results. N=309 observations. 
The study results displayed in Figure 3 suggest that women with the shortest industry-related work history (e.g. "1-5 years" category", $26.9 \%$ ) are more likely to establish and operate their own firms in the region than females with a very long industry-related work history (e.g. "26-30 years," $1.9 \%$ or " 31 and more years", $1.9 \%$ ). Thus, an implication of this study is that women with absolutely no prior industry-related work experience (i.e. $34.6 \%$ of respondents) or relatively short history of such expertise (i.e. $26.9 \%$ of respondents) may be much more inclined to become business owners in the Mazovia Province than females with a substantial industry-related work history (i.e. 1.9\% of respondents). This may be due to the "opportunity-pull" (e.g. desire for self-achievement) or "necessity-push" (e.g. difficulty in finding a job) motivational factors (Orhan, 2005).

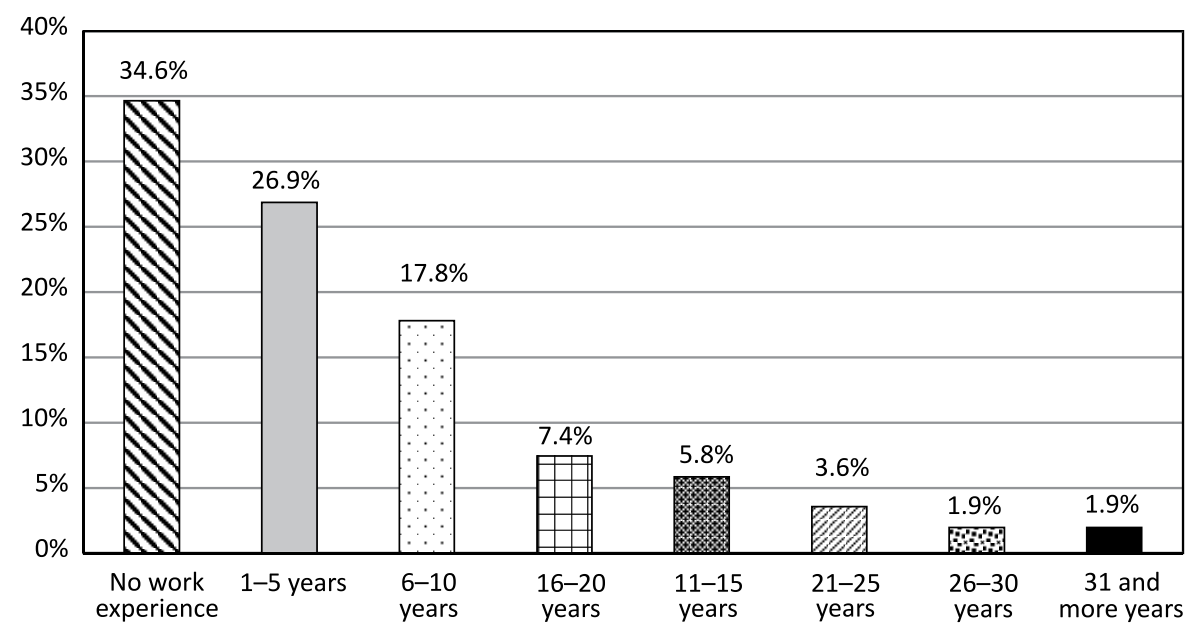

Figure 3. Professional work experience of women micro-entrepreneurs (\% share of total)

Source: own elaboration based on survey results. N=309 observations.

The findings shown in Figure 4 reveal that $34 \%$ of the surveyed women micro-entrepreneurs had "6-10 years" of business experience in the currently operated firms, while only $2.3 \%$ of females managed their existing companies for as long as " 26 or more years." The second largest category of women business owners (26.5\%) reported having "3-5 years" of practical business experience. Thus, the majority of the surveyed female micro-entrepreneurs (60.5\%) gained " $3-10$ years" of trading experience in the market. The average business experience of 
the investigated women business owners was about 11 years. However, the dominant number of female micro-entrepreneurs in the sample reported having only three years of practical experience in running their firms. This was also the minimum number of years required to participate in the survey. Consequently, most of the surveyed women micro-entrepreneurs at the end of 2013 owned and managed still relatively young and growing firms.

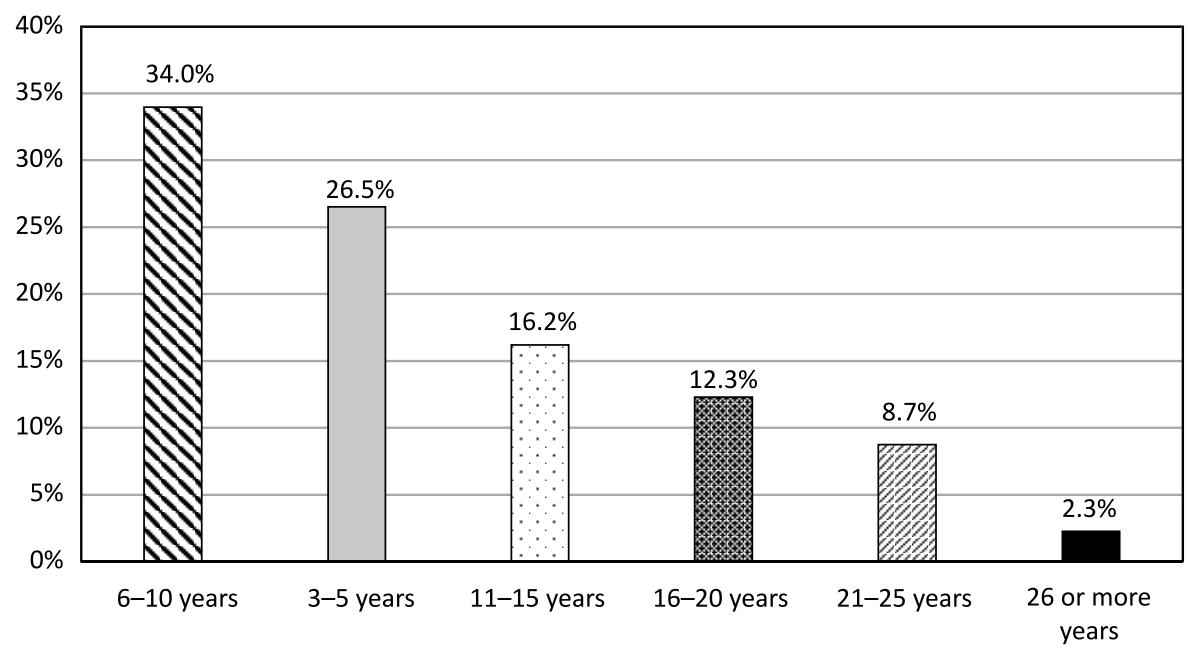

Figure 4. Business experience of women micro-entrepreneurs (\% share of total)

Source: own elaboration based on survey results. N=309 observations.

The study results in Figure 4 also show that about one-third of the surveyed women (26.5\%) entered into entrepreneurship during the world financial crisis of 2007-2008, or just in its aftermath. This suggests that their experience with business ownership may have begun due to mainly "necessity-push" motivational factors (e.g. loss of a job due to redundancy, unemployed status because of the financial crisis, etc.).

\section{The business goals of women micro-entrepreneurs}

The literature on women's entrepreneurial undertakings indicates that it is inappropriate to measure their accomplished success in business in terms of only quantitative financial indicators (e.g. annual sales revenue, profit after taxation, return on investment, etc.). This is because for most female entrepreneurs, in comparison with their 
male counterparts, the qualitative non-financial measures of success (i.e. the goals that are achieved through business ownership) are also very important (Fielden \& Davidson, 2010).

In the survey, women business owners from the Mazovia Province reported several business goals which, in their opinion, were the most important ones for the management of their firms, or to their direct family members. However, the study findings reveal that financial measures of success (e.g. profitability of the firm, company growth in terms of revenue, etc.) were not identified as the top priority goals to be pursued by females through business ownership.

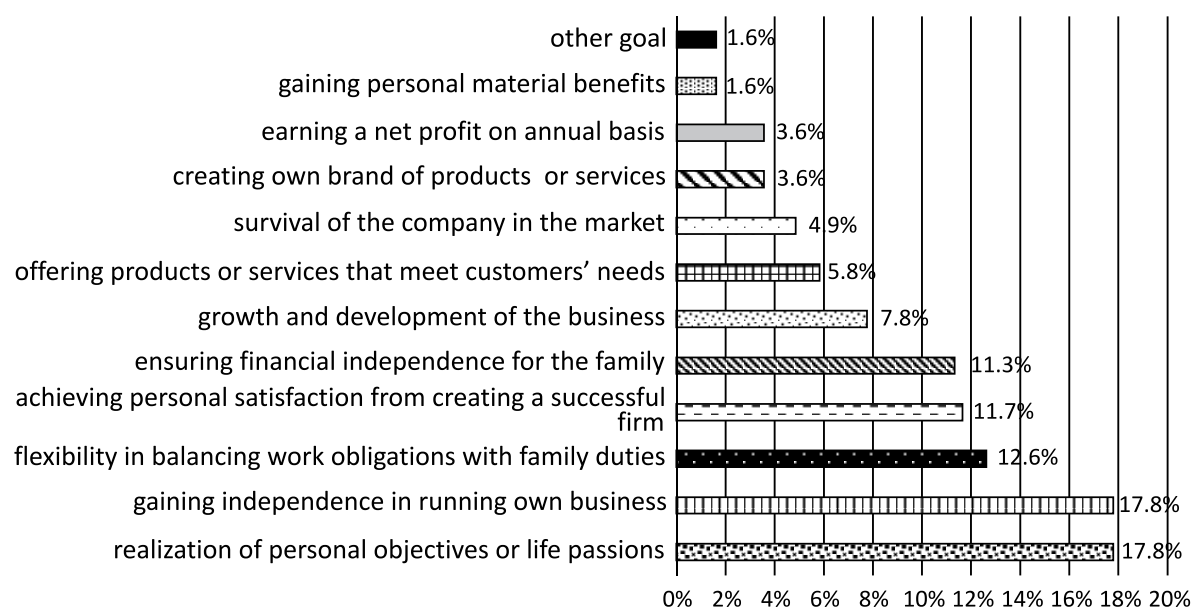

Figure 5. Most important goals for women in business ownership (\% share of total)

Source: own elaboration based on survey results. N = 309 observations.

Figure 5 reveals that personal goals are overwhelmingly the most important type of objectives pursued by women micro-entrepreneurs in the region. Specifically, the study results show that women micro-entrepreneurs jointly reported "realisation of personal objectives or life passions" (17.8\%), and "gaining independence in running own business" (17.8\%) as the two most important goals they pursued in the management of their firms. The most important financial goal reported by female micro-entrepreneurs, as an indicator of business success, was "growth and development of the business" (7.8\%).

Thus, the results of this study seem to confirm the international findings that non-financial qualitative goals are more important for 
many women micro-entrepreneurs than traditional quantitative financial indicators of success (i.e. sales revenue growth, profitability, etc.). The former are subjective in nature while the latter are performance-related. The choice of goals women pursue concerning business management may explain why female-owned firms are smaller than businesses owned by male entrepreneurs in terms of the number of employees, and the annual sales revenue generated.

\section{Business strategy adopted by women micro-entrepreneurs}

Many studies indicate that a necessary condition for the long-term survival of women-owned micro-enterprises is that their owners focus their attention on the future growth of their firms (Brush et al., 2006). To achieve this aim requires that female micro-entrepreneurs are able to identify and implement an appropriate business strategy for their firms (Grant, 2010). In turn, the adoption of a strategic approach concerning firm management enables women business owners to more effectively compete with their rivals in the industry (in the short to medium-term) in a more turbulent marketplace. Moreover, it also allows them to grow their micro-enterprises into larger business entities in the long-run. This may be accomplished through the additional equity injection into the business (e.g. acquisition of new partners; venture capital funds, etc.) or by debt financing (e.g. bank loans).

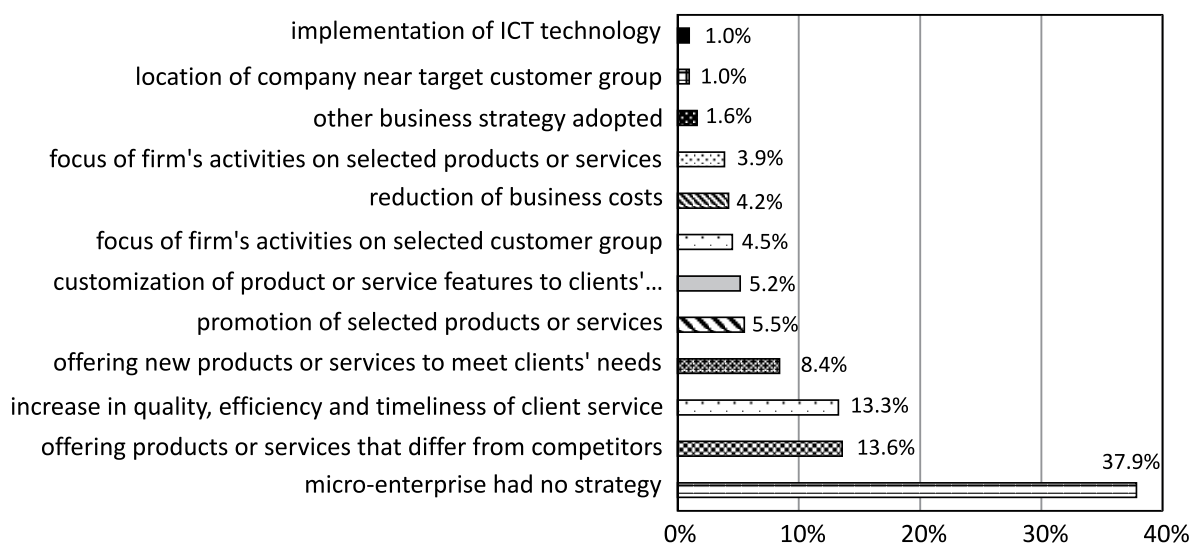

Figure 6. Business strategies adopted by women micro-entrepreneurs during 2011-2013 (\% share of total)

Source: own elaboration based on survey results. N = 309 observations. 
Figure 6 shows that about two-thirds (62.1\%) of the surveyed women-owned micro-enterprises from the Mazovia Province used a specific business strategy to gain a competitive advantage over their rivals in the industry during 2011-2013. The most often implemented strategies by the female micro-entrepreneurs concerned "offering products or services that differ from competitors" (13.6\%) and "increase in quality, efficiency and timeliness of client service" (13.3\%). The adoption of these two specific strategic approaches enabled many women business owners, especially those operating within the consumer services industry, to successfully contend with their rivals during 2011-2013.

However, the study findings revealed that only a handful of female business owners (1\%) reported adopting strategies that focused on new technology implementation or innovative capacity of their firms. Such specific strategies could provide many women-owned firms a much greater competitive edge over their rivals in the long-run. Moreover, specific business growth strategies such as "market expansion to new geographical locations," "acquisition of another firm," or "a company merger" were also not reported by the surveyed female-owned micro-enterprises. This may perhaps be explained by the fact that women micro-entrepreneurs had either no funds to consider a long-term business development of their firms, or lacked the expertise in this area.

\section{The resources and firm characteristics of women-owned micro-enterprises}

Figure 7 reveals that the overwhelming majority $(91.9 \%)$ of the surveyed women micro-entrepreneurs in the region operated their firms as sole proprietors. On the other hand, registered partnership $(2.3 \%)$ was the least popular legal structure chosen by women during 2011-2013. The selection of sole proprietorship by females as a legal form may be associated with, for example, the following factors: "the ease of establishment and operation of the firm;" "significantly much lower cost of management and reporting than for incorporated legal entities;" "predominant reliance on own financial resources;" "having no staff or hiring less than five employees at start-up;" "the lack of external sources of capital at start-up;" "no prior business experience;" "the absence of or very limited usage of business networks;" "narrow industry awareness;" as well as "the shortage of professional management skills acquired within larger organisations." 


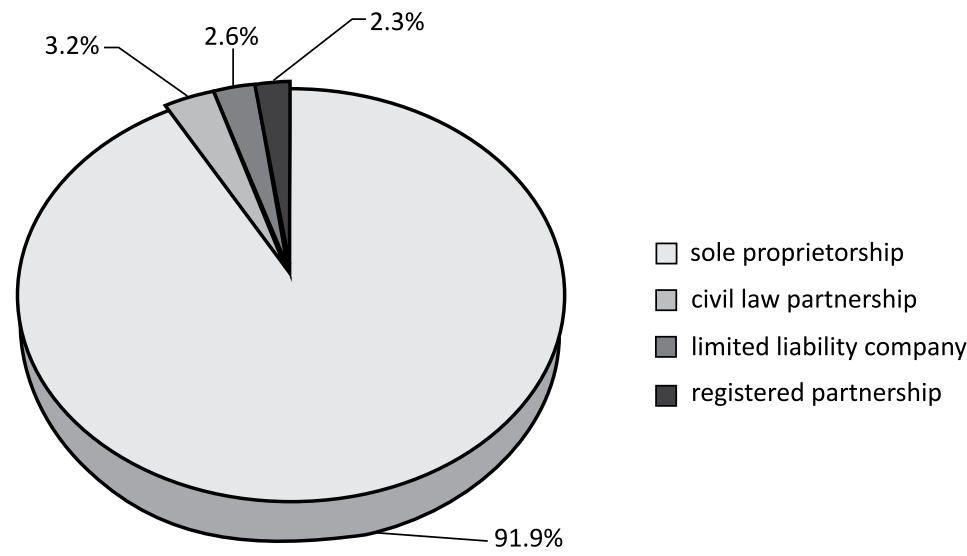

Figure 7. The legal form of women-owned micro-enterprises (\% share of total)

Source: own elaboration based on survey results. N=309 observations.

Figure 8 shows that women micro-entrepreneurs in the region are predominately active in the consumer services sector of the economy (72.8\%). The second most popular economic activity chosen by females was "retail and wholesale trade" (16.2\%). In turn, "construction" (2.6\%); "transportation and storage" (1.6\%); as well as "agriculture, hunting and fishing" (1.3\%) are the economic activities in which women business owners are the least engaged in.

It may be argued that the selection by female business owners from the Mazovia Province of a specific economic activity, in which they are willing to be active, reflects their completed education level and its profile, their prior professional work history, as well as their acquired industry-related business experience.

Figure 9 reveals that the majority of the surveyed women-owned micro-enterprises within the region had their primary seat of business operations located in the capital city of Warsaw (58.9\%). In turn, as much as $30.1 \%$ of the studied female-owned firms were registered in other cities of various sizes in terms of the number of residents. Outside of Warsaw, most women micro-entrepreneurs reported that the main location of their business was situated in a "city of 20,000 to 50,000 residents" (9.7\%), which was closely followed by a "city of 5,000 to 20,000 residents" (8.4\%). However, as much as $11 \%$ of the respondents cited that their firms were located in villages within various rural boroughs (i.e. "gminy") of the Mazovia Province. 


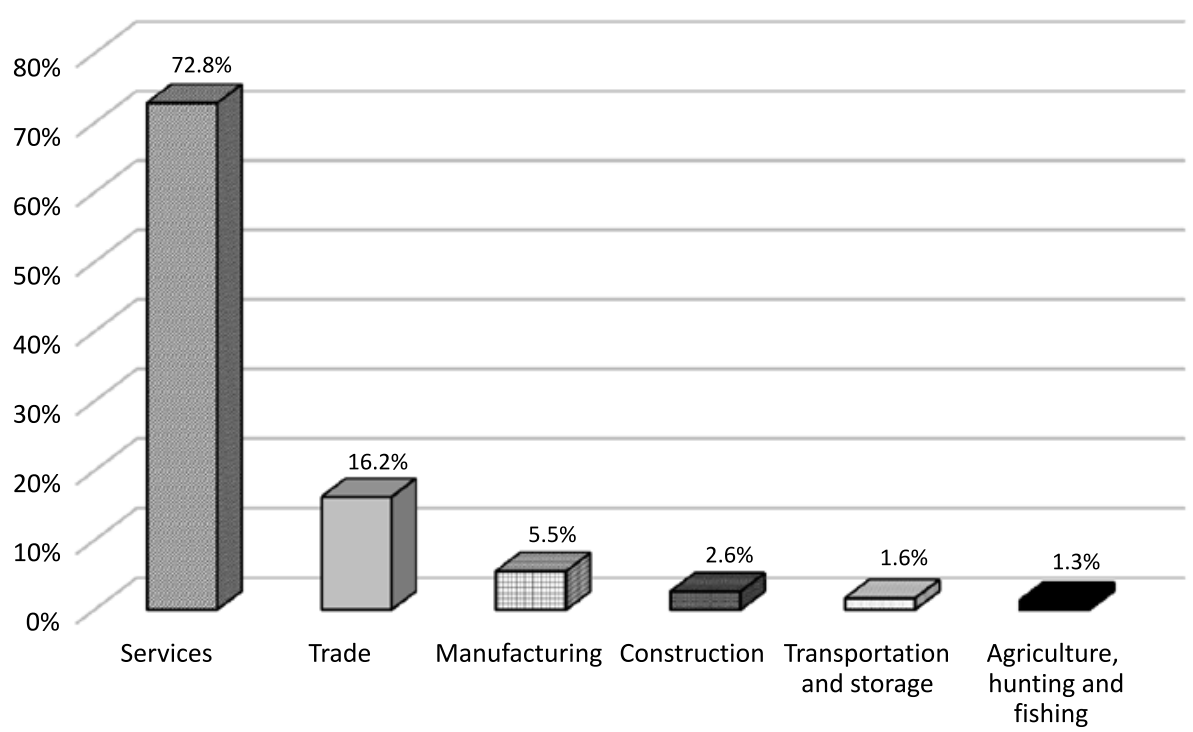

Figure 8. The primary type of economic activity undertaken by women-owned micro-enterprises (\% share of total)

Source: own elaboration based on survey results. N = 309 observations.

The selection of the capital city of Warsaw as the main seat of business operations by most of the surveyed women business owners should not come as a surprise. This is because it is viewed as one of the most attractive cities for investment purposes and doing business in Poland. The factors that make Warsaw so appealing for many women-owned micro-enterprises are: "the largest market size in Poland;" "first place in Poland regarding gross domestic product per capita;" "strong future economic growth potential;" "the role of the capital as the country's main decision-making center;" "macroeconomic stability;" "good quality of infrastructure and business environment;" "well-developed and convenient transport connections;" as well as "a large pool of educated and qualified human capital" (PAIiIZ, 2016).

The findings of this research shown in Figure 10 suggest that most of the surveyed female business owners from the Mazovia Province prefer to offer their products, or render their services to customers as self-employed entities rather than choose to become employers. Consequently, Figure 10 shows that in terms of the size of the micro-enterprise, measured in terms of the number of workers in 2013 (year's end self-reported data), as much as 54.7\% female-owned firms 
traded as self-employed business entities. In turn, $21.7 \%$ employed "1-2 employees", $15.5 \%$ hired " $3-5$ staff members." In comparison, $8.1 \%$ of the largest micro-enterprises under study had more than six workers as on December 31 ${ }^{\text {st }}, 2013$.

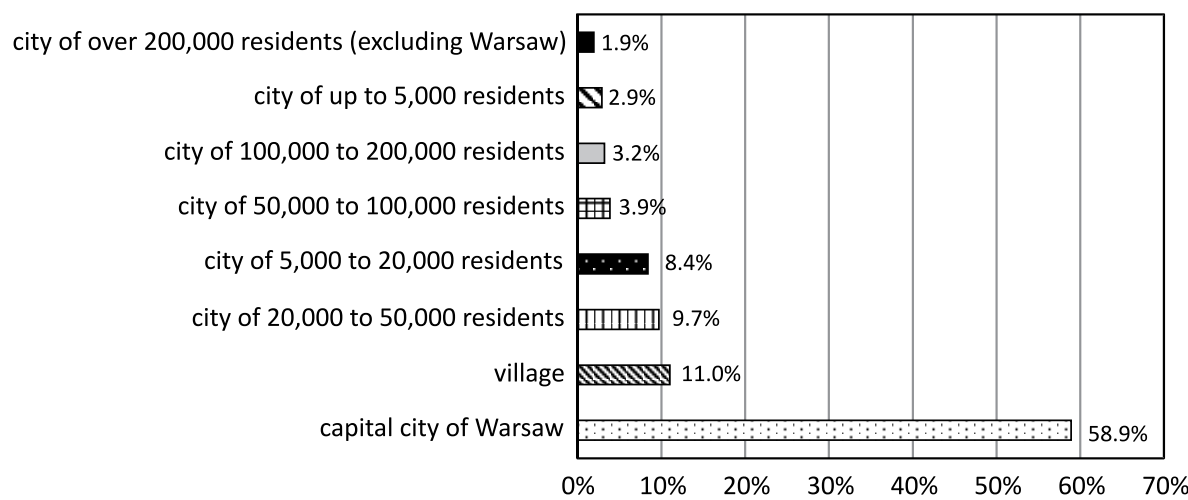

Figure 9. The business location of women-owned micro-enterprises (\% share of total)

Source: own elaboration based on survey results. N=309 observations.

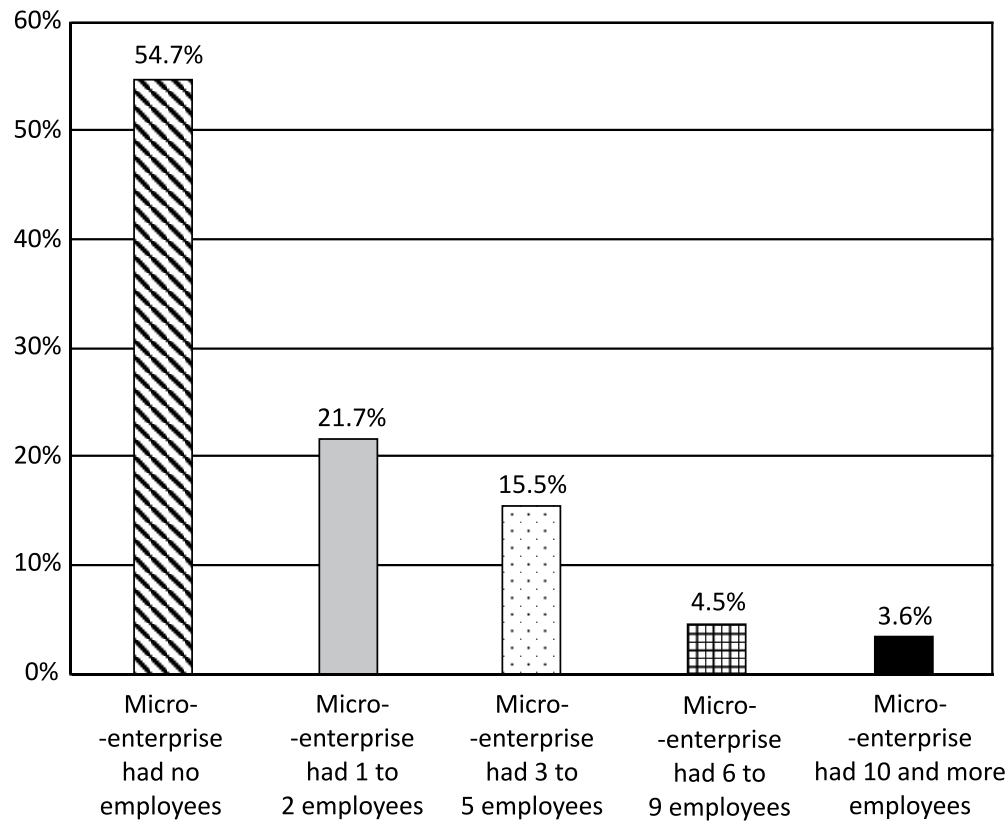

Figure 10. The size of women-owned micro-enterprises as on December 31 st, 2013 in number of employees (\% share of total)

Source: own elaboration based on survey results. N=309 observations. 
The decision made by women to operate as self-employed business entities since start-up may be associated with the need to cope with the increased competition in the marketplace by reducing operating costs. Many female micro-entrepreneurs would like to hire staff members, but they cannot afford to do so in a highly competitive marketplace. The presence of so many women-owned firms within the region that are managed as self-employed entities may also be explained by their predominant reliance on very limited internal financial resources such as own savings and retained earnings (see Figure 11).

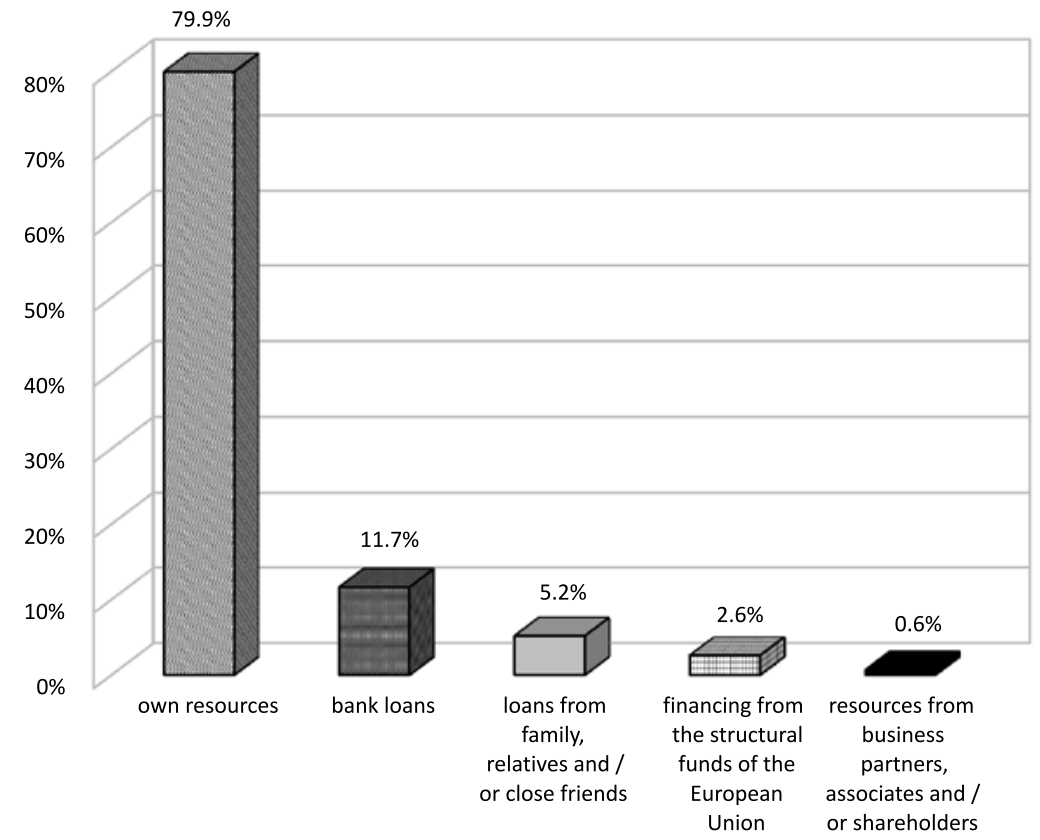

Figure 11. The main source of funding of women-owned micro-enterprises (\% share of total)

Source: own elaboration based on survey results. N=309 observations.

Finally, Figure 11 reveals that an overwhelming majority of women micro-entrepreneurs (79.9\%) reported internal financial resources (e.g. retained earnings, personal savings, etc.) as their main source of funding of their business operations during 2011-2013. In turn, the largest external source of finance used by female business owners was associated with bank loans (11.7\%). However, only $2.6 \%$ of the surveyed women declared that they applied for and received some form of financial support from the European Union structural funds. They used this form of external 
finance to fund their current operations and investment needs. The overwhelming reliance of women-owned micro-enterprises on limited internal sources of finance may restrict the growth aspirations of many of these female business owners. Moreover, it also explains to some extent why they tend to operate their firms as self-employed entities instead of becoming employers in the local marketplace.

\section{DISCUSSION AND CONCLUSIONS}

The majority of women micro-entrepreneurs from the Mazovia Province were in their 30s or 40s and completed some form of tertiary education. Similar findings are reported in most of the developed countries around the world (Taylor \& Newcomer, 2005). However, in many developing nations younger women participate in business undertakings at the same or closely similar rate as the older generation of females do (Kelley et al., 2013).

About slightly over one-third of the surveyed women business owners had no prior industry-related work experience before becoming entrepreneurs. This may suggest that they started their firms being motivated by "necessity-push" factors like experienced difficulty in finding a full-time job or having a status of being unemployed. In comparison, in innovation-driven economies (e.g. the USA) most women enter into entrepreneurship by "opportunity-pull" motivations such as "the desire to build wealth," "the wish to capitalize on business ideas they had" or "a long-standing desire to own their own company" (McGrath Cohoon et al., 2010, pp. 4-5).

The average business experience of female business owners in the sample was around 11 years. However, as much as one-third of the surveyed women set up their own firms during the beginning of the 2007-2008 world financial crisis. Thus, they exhibited very little or no practical business skills in running their businesses during the year of company formation. In comparison, modern women entrepreneurs in developed market-based countries report having several years of previous managerial experience before entering into entrepreneurship (Taylor \& Newcomer, 2005).

The overwhelming majority of the surveyed women business owners operated their firms as sole proprietors. A similar pattern appears to be occurring around the world as most female-run firms start out with 
only a single owner (Kelley et al., 2013). The studied female micro-entrepreneurs operated predominately within the services sector of the economy. However, wholesale and retail trade was the second largest sector in which they were engaged in. A similar trend is prevalent across the globe because on average about half of female business owners are active within the consumer services sector (Kelley et al., 2015).

One of the most important outcomes of entrepreneurship is the creation of new jobs in countries. However, from the historical perspective, it is known that women business owners usually establish much smaller firms than do male entrepreneurs as measured by the size of the enterprise in terms of the number of employees (Kelley et al., 2013). The findings of this study appear to confirm this prevailing pattern. Consequently, most of the surveyed women-owned firms traded as self-employed legal entities and sole proprietorships that did not hire any employees.

Women are more likely to establish and run their firms as self-employed entities in contrast with businesses that are owned by men. As a result, in developing and emerging economies, most female entrepreneurs operate their firms as sole traders who do not hire workers. In comparison within innovation-driven countries, women-owned businesses that trade as self-employed entities are fewer in numbers than in factor- and efficiency-driven economies (Kelley et al., 2015).

Almost two-thirds of the surveyed female business owners used a business strategy to gain an advantage over their competitors during 2011-2013. The most often implemented strategies by women in the region were associated with "offering products or services that differ from competitors" and "increase in quality, efficiency and timeliness of client service." However, over one-third of researched women micro-entrepreneurs failed to identify the need to adopt a business strategy in order to effectively compete with their industry rivals. Such lack of awareness of existing environmental threats may not bode well for the survival of these firms in the near future. Moreover, adopting a viable business strategy by micro-enterprises is an important factor in achieving success in a competitive marketplace (Lemańska-Majdzik, 2009).

The majority of the investigated female business owners reported that during 2011-2013 their primary source of financing of the firm operations originated from internal sources. However, only about one-tenth of women micro-entrepreneurs declared using an external source of funding in the form of bank loans. Similarly, in developed 
countries, women-owned firms finance their business operations mainly by personal savings, retained earnings, and contributions from family members. The largest source of external supplementary funding originates from debt financing provided by commercial banks. Only a minority of female business owners take advantage of government support, equity financing from venture capital or private investment. Moreover, gaining access to the required amount of funds to finance business operations poses a challenge for many women micro-entrepreneurs in many countries (Marlow \& Patton, 2005).

\section{Suggestion for further research}

The findings discussed herein provide the academic community with a better understanding of the operation of women-owned micro-enterprises within the context of the Polish experiences.

Women's business ownership is viewed by scholars around the world as "a dynamic social and economic phenomenon" (Leszczyński, 2013, pp. 120-123). Therefore, future studies may consider investigating independent variables from the process (e.g. the recruitment, training, and retention of employees), and the macro- or micro-environment (e.g. the nature of maintained relationships with customers, suppliers, or partners), in which female-owned firms operate (Leszczyński, 2016).

Moreover, it is recommended that similar studies are undertaken in less economically developed regions of Poland (e.g. Warmia-Masuria Province), as well as in countries from Central and Eastern Europe (e.g. Czech Republic) to be used for comparative purposes. In order to obtain a more complete picture of the investigated phenomenon, prospective scientific inquiries may also compare the populations of male and female micro-entrepreneurs in different contexts.

\section{REFERENCES}

Aldrich, H.E., Carter, N.M. \& Ruef, M. (2002). With very little help from their friends: Gender and relational composition of nascent entrepreneurs' startup teams, Frontiers of Entrepreneurship Research (FER), Babson College Entrepreneurship Research Conference (BCERC), online conference proceedings. Wellesley, MA: Babson College. Retrieved from: https:/fusionmx.babson. edu/entrep/fer/Babson2002/VI/VI_P1/VI_P!.html (acces: November 2, 2016). 
Allen, I.E., Langowitz, N. \& Minniti, M. (2007). The Global Entrepreneurship Monitor: 2006 Report on Women and Entrepreneurship. Wellesley, MA: The Center for Women's Leadership at Babson College, The Global Entrepreneurship Research Association (GERA), Babson College \& London Business School.

Balcerzak-Paradowska, B., Bednarski, M., Głogosz, D., Kusztelak, P., Ruzik-Sierdzińska, A. \& Mirosław, J. (2011). Women Entrepreneurship in Poland. Warsaw: Polish Agency for Enterprise Development (PARP).

Brush, C.G., Carter, N.M., Gatewood, E.J., Greene, P.G. \& Hart, M.M. (2006). Introduction: the Diana Project International. In: C.G. Brush, N.M. Carter, E.J. Gatewood, P.G. Greene \& M.M. Hart (eds.), Growth-oriented Women Entrepreneurs and their Businesses (first ed., pp. 3-22). Cheltenham: Edward Elgar Publishing Ltd.

Bryman, A. \& Bell, E. (2011). Business Research Methods (third ed.). Oxford: Oxford University Press.

Buttner, D.P. \& Moore, E.H. (1997). Women Entrepreneurs: Moving Beyond the Glass Ceiling. Thousand Oaks, CA: Sage Publications Inc.

Carter, S., Marlow, S. \& Bennett, D. (2012). Gender and entrepreneurship. In: S. Carter \& D. Jones-Evans (eds.), Enterprise and Small Business: Principles, Practice and Policy (third ed., pp. 218-231). Harlow: Pearson Education Ltd.

Coleman, S. (2000). Access to capital and terms of credit: A comparison of men- and women-owned small businesses, Journal of Small Business Management, 38(3), pp. 37-52.

Fielden, S.L. \& Davidson, M.J. (2010). Introduction. In: S.L. Fielden \& M.J. Davidson (eds.), International Research Handbook on Successful Women Entrepreneurs (first ed., pp. 1-9). Cheltenham: Edward Elgar Publishing Ltd.

Gartner, W.B. (1985). A conceptual framework for describing the phenomenon of new venture creation, Academy of Management Review, 10(4), pp. 696-706.

Grant, R.M. (2010). Contemporary Strategy Analysis: Text and Cases (7 $7^{\text {th }}$ ed.). Chichester: John Wiley \& Sons Ltd.

Guzowska, M. (2011). Mazovia in brief: Economy [Samorząd Województwa Mazowieckiego (the Regional Council of Mazovia Voivodeship)]. Retrieved April 10, 2016 from http://www.mazovia.pl/en/shortly-about-mazovia/mazovia-in-brief/ art,2,economy.html

Kelley, D.J., Brush, C.G., Greene, P.G. \& Litovsky, Y. (2013). The Global Entrepreneurship Monitor: 2012 Women's Report. Wellesley, MA.: The Global Entrepreneurship Research Association (GERA), The Center for Women's Leadership at Babson College, Babson College, London Business School, Universidad Del Desarrollo \& Universiti Tun Abdul Razak.

Kelley, D.J., Brush, C.G., Greene, P.G., Herrington, M., Ali, A. \& Kew, P. (2015). The Global Entrepreneurship Monitor Special Report: Women’s Entrepreneurship 
2014. Wellesley, MA: The Global Entrepreneurship Research Association (GERA), The Center for Women's Leadership at Babson College, Babson College, Universidad del Desarrollo, Universiti Tun Abdul Razak \& Tecnológico de Monterrey.

Lemańska-Majdzik, A. (2009). Czynniki sukcesu firm powstałych w wyniku samozatrudnienia. Częstochowa: Sekcja Wydawnictwa Wydziału Zarządzania Politechniki Częstochowskiej.

Leszczyński, D. (2013). The investigation into motivations, success factors and barriers among women small business owners: An overview of extant literature, International Journal of Management and Economics, 39(1), pp. 108-125.

Leszczyński, D. (2016). Exploration of key success factors that influence business performance: The experiences of women micro-entrepreneurs from Mazovia Voivodeship of Poland, International Journal of Management and Economics, 51(1), pp. 63-89.

Marlow, S. \& Patton, D. (2005). The financing of small businesses - female experience and strategies. In: S.L. Fielden \& M.J. Davidson (eds.), International Handbook of Women and Small Business Entrepreneurship (first ed., pp. 66-77). Cheltenham: Edward Elgar Publishing Ltd.

McGrath Cohoon, J., Wadhwa, V. \& Mitchell, L. (2010). The Anatomy of an Entrepreneur: Are Successful Women Entrepreneurs Different from Men. Kansas City, MO: Ewing Marion Kauffman Foundation.

Orhan, M. (2005). Why women enter into small business ownership? In: S.L. Fielden \& M.J. Davidson (eds.), International Handbook of Women and Small Business Entrepreneurship (first ed., pp. 3-16). Cheltenham: Edward Elgar Publishing Ltd.

PAIiIZ (The Polish Information and Foreign Investment Agency) (2016). Polish regions: Mazowieckie Voivodeship. Warsaw: Polska Agencja Informacji i Inwestycji Zagranicznych (PAIiIZ). Retrieved from: http://www.paiz.gov. pl/polish_regions/voivodships/mazowieckie (access: March 30, 2016).

Taylor, S.R. \& Newcomer, J.D. (2005). Characteristics of women small business owners. In: S.L. Fielden \& M.J. Davidson (eds.), International Handbook of Women and Small Business Entrepreneurship (first ed., pp. 17-31). Cheltenham: Edward Elgar Publishing Ltd.

Valencia, M. (2007). Past female entrepreneurship with the stress on the future in the new economy globalization. In: M. Radović Marković (ed.), The Perspective of Women's Entrepreneurship in the Age of Globalization (first ed., pp. 13-23). Charlotte, NC: Information Age Publishing Inc.

Zikmund, W.G., Babin, B.J., Carr, J.C. \& Griffin, M. (2009). Business Research Methods (eighth ed.). Mason, OH: South-Western College Publishing. 


\title{
KOBIETY MIKROPRZEDSIĘBIORCZYNIE Z WOJEWÓDZTWA MAZOWIECKIEGO: REALIZOWANE CELE, PRZYJĘTA STRATEGIA BIZNESOWA ORAZ CHARAKTERYSTYKA ZARZĄDZANYCH FIRM
}

\begin{abstract}
Abstrakt
Tło badań. Mikroprzedsiębiorstwa zarządzane przez kobiety przyczyniają się do tworzenia nowych miejsc pracy oraz wartości dodanej w wielu krajach na całym świecie. Jednakże firmy te do tej pory zostały jeszcze niedostatecznie przebadane w krajach z Europy Środkowej i Wschodniej.

Cel badań. Pierwszym celem badania było określenie cech społeczno-demograficznych kobiet przedsiębiorczyń z województwa mazowieckiego. Natomiast drugim celem badania było opisanie zasobów oraz dokonania charakterystyki zarządzanych przez kobiety mikroprzedsiębiorstw.
\end{abstract}

Metodologia. Badanie przeprowadzono metoda internetowego wywiadu kwestionariuszowego, które zlecono do realizacji profesjonalnej firmie badawczej w celu zapewnienia wysokiej jakości procesu gromadzenia danych empirycznych. Do analizy 309 poprawnie wypełnionych kwestionariuszy wykorzystano miary i współczynniki statystyki opisowej.

Kluczowe wnioski. Przedsiębiorcze kobiety z regionu prowadzą firmy głównie w formie jednoosobowej działalności gospodarczej, które funkcjonuja najczęściej w sektorze usług. Firmy te wykorzystują własne środki pieniężne w celu finansowania działalności gospodarczej. Prowadząc własne mikroprzedsiębiorstwa, kobiety staraja się najczęściej urzeczywistnić własne niefinansowe cele prywatne (np. "realizacja osobistych celów i/lub pasji życiowych"). Ponadto, wykorzystują one w praktyce nieformalne strategie biznesowe, aby osiagnać przewagę nad konkurentami z branży. Strategie te dotyczą zróżnicowania oferty produktów i/lub usług, poprawy jakości świadczonych usług, bądź koncentracji działań na określonym segmencie obsługiwanych klientów. Jednakże, strategie biznesowe stosowane przez przedsiębiorcze kobiety rzadko dotyczą długoterminowego rozwoju zarządzanej firmy.

Słowa kluczowe: cel biznesowy, strategia biznesowa, mikroprzedsiębiorstwo, Polska, przedsiębiorcza kobieta. 